\title{
Contaminant Trends in Sport Fish from Lake Roosevelt and the Upper Columbia River, Washington, 1994 to 1998
}

\author{
By Mark D. Munn
}

\section{ABSTRACT}

Fish from Lake Roosevelt were first reported to contain elevated concentrations of contaminants in the early 1980's, with mercury, dioxins and furans, and polychlorinated biphenyls (PCBs) identified as being of most concern to human health. Over the following years there were a series of studies by United States and Canadian agencies addressing contaminants in fish from both a human and environmental perspective. In the early 1990's, industrial discharges to the Columbia River above the international boundary decreased. The dominant changes in industrial practices included a reduction in slag and effluent discharges from a lead-zinc smelter, and a reduction in dioxins and furans due to processing changes at a Canadian pulp mill. It is believed that these two alterations in industrial practices may have greatly reduced the loading of selected contaminants to the Columbia River system. In response to these recent changes, the U.S. Geological Survey initiated this present study for the purpose of determining the present concentrations of mercury, dioxins and furans, and PCBs in fish, and, if possible, to determine if concentrations have changed since the 1994 studies. All contaminant analysis was done on fish fillets in order to address human health concerns.

Our study concluded that the concentrations of contaminants in fish that were identified as a potential threat to human health have either not changed since the 1994 studies, or have decreased. PCBs, as determined by Aroclor 1254, do not appear to have changed between 1994 and 1998; sources of PCBs are presently unknown. In contrast, dioxins and furans, as indicated by 2,3,7,8-TCDF, did show a significant decrease in rainbow trout fillets from 1994 to 1998 . However, there was no apparent change in the average 2,3,7,8-TCDF concentrations in mountain whitefish, with the reason uncertain at this time.

Average concentrations of 2,3,7,8-TCDF were higher in mountain whitefish than in rainbow trout. Toxicity equivalence concentrations (TEC) are determined by summing the relative toxicity of individual congeners of dioxins, furans, and toxic "dioxin-like" PCB congeners in individual fish. Rainbow trout from the upper reach have higher TECs than rainbow trout from the lower reach, with trout from the upper reach having a higher percentage of the toxicity from toxic "dioxin-like" PCBs than dioxin and furan compounds. In relation to mercury, the concentrations of total mercury in walleye have significantly decreased by about 50 percent from 1994 to 1998.

\section{INTRODUCTION}

The upper Columbia River, including Lake Roosevelt, is of great regional importance due to its extensive recreational use and fishery resources (fig.1). Studies in the 1980's reported that concentrations of specific contaminants in sport fish were high enough to pose a potential threat to human health. Contaminants of most concern were mercury and several organochlorine compounds, including dioxins and furans and PCBs. In response to concerns about the potential threat of these contaminants to the environment and human health, the Lake Roosevelt Water 


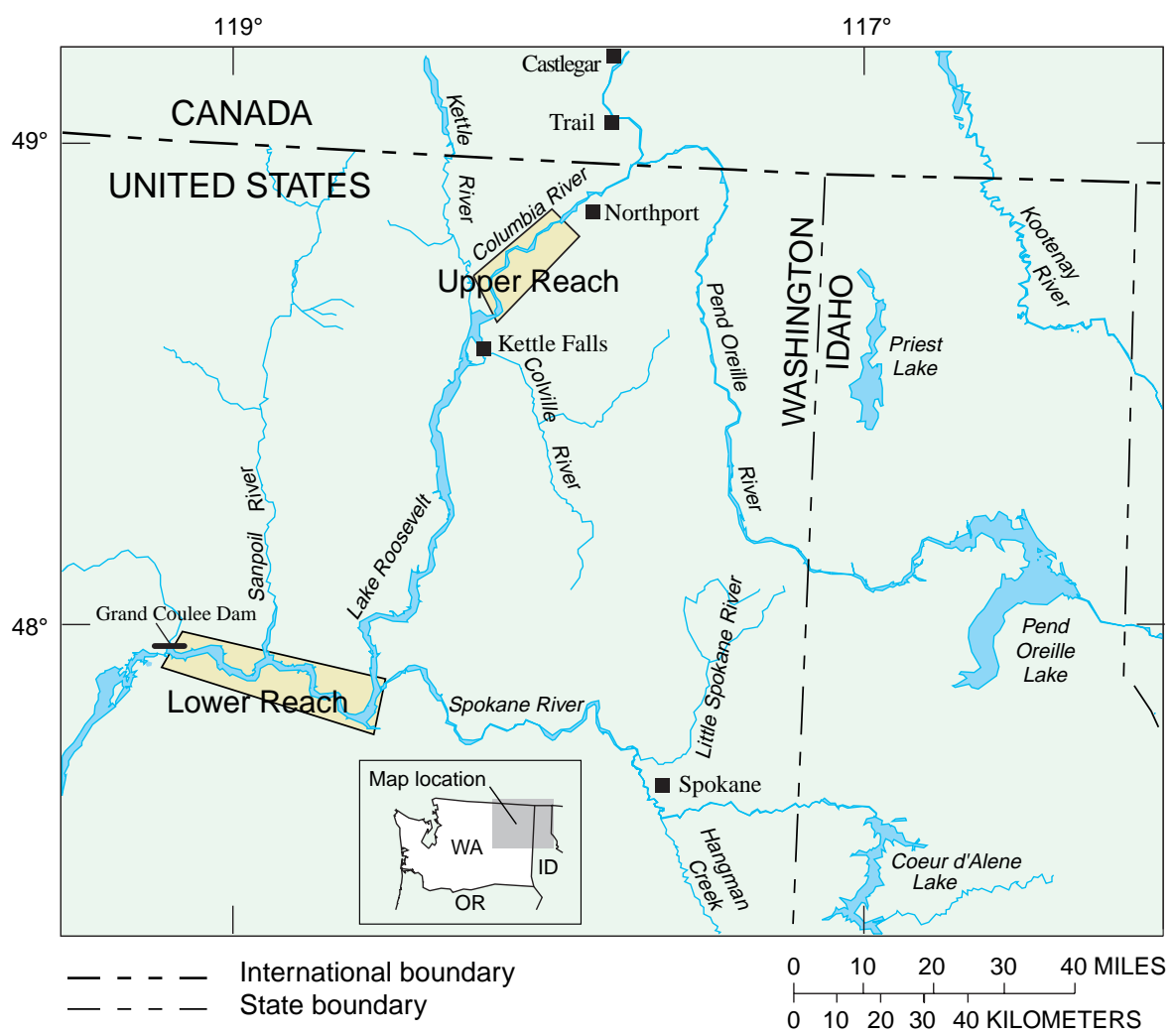

Figure 1. Lake Roosevelt in the upper Columbia River, including the upper sampling reach between Northport and Kettle Falls, and the lower sampling reach from the Spokane River to Grand Coulee Dam, Washington.

Quality Council (LRWQC) was organized in 1990 consisting of local citizen groups, the Colville Confederated and Spokane Tribes, and various government agencies. The LRWQC, in cooperation with the U.S. Environmental Protection Agency (USEPA), Washington Department of Ecology (WDOE), and U.S. Geological Survey (USGS), have investigated contaminants in Lake Roosevelt fish. In the late 1980's, Canadian scientists reported elevated concentrations of dioxins and furans in Lake Roosevelt whitefish collected from the upper Columbia River (Mah and others, 1989), resulting in Health and Welfare Canada issuing a health advisory. In response to this, the WDOE determined that dioxins and furans were present in sport fish collected from Lake Roosevelt (Johnson and others, 1991). This was followed up by a number of additional studies dealing with different species and locations. The most recent study of organochlorine compounds in fish tissue was the 1994 USEPA study (EVS Consultants, 1998) that analyzed dioxins, furans, and PCBs in sport fish tissue for the purpose of investigating human health concerns. One of the more important findings of the 1994 study was that concentrations of dioxins and furans had decreased in fish over time. The most recent mercury study done by the USGS in 1994 resulted in the Washington Department of Health (DOH) issuing a fish consumption advisory (Erwin and Munn, 1997).

In the early 1990's, industrial discharges to the Columbia River above the international boundary decreased. Slag and effluent discharge from the Cominco lead-zinc smelter upstream in Trail, British Columbia (B.C.) were reduced. In addition, changes in bleaching and wastewater treatment processes at the pulp mill in Canada have improved the quality of effluent discharged to the Columbia River (Serdar and others, 1994). It is believed that these two changes in industrial practices have reduced the loading of mercury, dioxins, and furans to the Columbia River system. In response to these recent changes in 
industrial discharges, the LRWQC requested that the USGS initiate this follow-up fish tissue study. The objective of this study was to determine the present concentrations of mercury, dioxins and furans, and PCBs, and, if possible, determine if concentrations have changed since the 1994 studies.

\section{Acknowledgments}

This study could not have been completed without the assistance of many individuals and organizations. I thank the Spokane Tribe along with Brett Smith and Ray Smith of the USGS for collecting the fish. Dorene MacCoy provided technical assistance throughout the report. Dennis Helsel, Robert Black, and Frank Ossiander provided statistical assistance. I also thank Bernie Bonn, Gil Bortelson, Sharon Fitzgerald, Patty Stone, and Glenn Patrick for technical reviews. This report was produced by Connie Dean (Illustrator), Ginger Renslow (Publication Editor), and John Clemens (Technical Editor) of the Washington District Technical Communication Section. This study was funded by the Lake Roosevelt Water Quality Council and administrated by the Colville Confederated Tribes.

\section{OVERVIEW OF CONTAMINANTS}

The purpose of this section is to provide an overview of the contaminants presented in this study and therefore present basic information on PCB Aroclors, dioxins and furans, toxic "dioxin-like" PCB congeners, and mercury. Also presented is an overview of the calculation of toxicity equivalence concentrations (TECs) that are used to determine total combined toxicity of dioxins, furans, and toxic "dioxin-like" PCB congeners.

\section{PCBs}

Polychlorinated biphenyls (PCBs) are a class of 209 individual organic chemical compounds. The basic PCB structure is shown in figure 2. Individual PCBs, called congeners, differ from one another in the number of chlorine atoms that they contain (1 to 10) and in the relative positions of those atoms within the molecule. PCBs are chemically and physically stable, and they have excellent insulating properties that made them popular for use in transformers and other electrical equipment. In addition, PCBs were used in inks, paint, plastics, as pesticide extenders, and for other applications. At their peak production in 1970, 38,600 tons of PCBs were produced in the United States (Smith and others, 1988). No known natural sources of PCBs exist. Because of their chemical stability, they are long-lived in the environment. PCBs are structurally similar to the pesticide DDT and cause some of the same abnormalities in wildlife, including eggshell thinning in birds and decreased reproduction of aquatic species. In humans, PCBs have been linked to abnormalities of the immune, reproductive, nervous, and endocrine systems (EVS Consultants, 1998). Some PCB congeners are thought to act by the same biochemical mechanism as dioxins and furans and are called toxic "dioxin-like" PCBs. USEPA has classified all PCBs as probable human carcinogens. Because of their toxicity and environmental persistence, manufacture of PCBs in the United States ceased in 1977. WDOE has set a screening value for total PCBs in edible fish tissue of $1.4 \mu \mathrm{g} / \mathrm{kg}$ (micrograms per kilogram) (Johnson and others, 1994). This value was developed using USEPA risk assessment guidelines and is based on an increased risk level of 1 cancer in 1 million (USEPA, 1995). When they were being produced, PCBs were marketed as mixtures of congeners under the trade name Aroclor. Because of this, studies have historically analyzed for PCB mixtures, rather than individual congeners. In addition, congenerspecific analysis of PCBs is difficult because of the large number of congeners. Previous studies of Lake Roosevelt and the upper Columbia River analyzed for three Aroclor mixtures $(1242,1254$, and 1260) and no analyses for individual, toxic "dioxin-like" PCB congeners in Lake Roosevelt fish have been reported prior to this study.

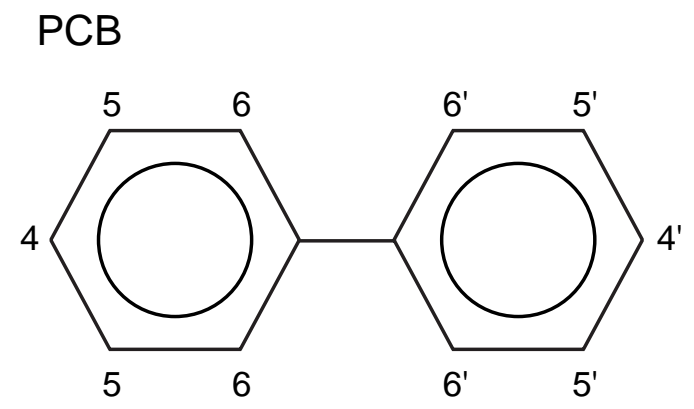

Figure 2. Schematic of polychlorinated biphenyl (PCB). The numbers indicate the position of the chlorine atoms; 6 , chlorine atom in the 6 th position; 6 ', chlorine atom in the 6 th prime position. 

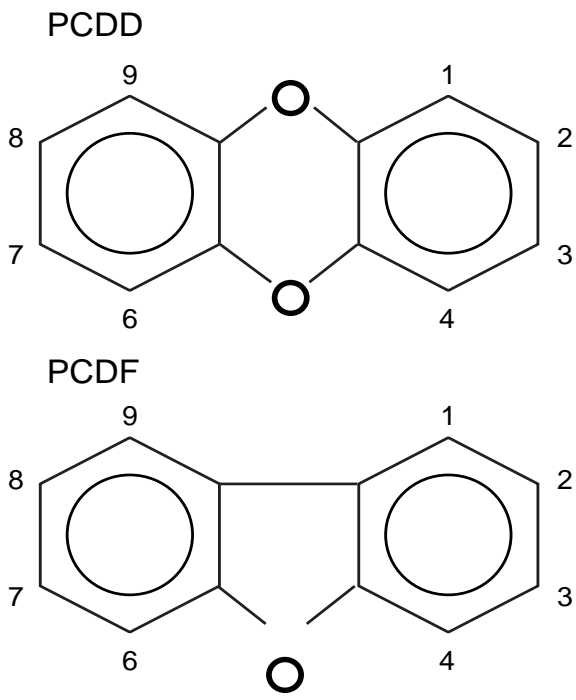

Figure 3. Polychlorinated dibenzo- $p$-dioxin $(P C D D)$ and polychlorinated dibenzofuran (PCDF) schematic. The numbers indicate the position of the chlorine atoms around an aromatic ring structure of carbon atoms; 6 , chlorine atom in the $6^{\text {th }}$ position.

\section{Dioxins and Furans}

Dioxins (polychlorinated dibenzo- $p$-dioxins (PCDDs)) and furans (polychlorinated dibenzofurans (PCDFs)) are formed as by-products of industrial chemical processes and during combustion of chlorinated organic compounds, incineration of municipal waste, and chlorine bleaching of wood pulp (fig. 3). They have no commercial or domestic applications and are not produced intentionally. There are 75 different types of dioxins, of which 2,3,7,8-tetrachlorodibenzo$p$-dioxin (2,3,7,8-TCDD) is the most toxic and therefore widely studied. PCDFs are chemically similar to PCDDs and occur in 135 forms. Most significant of the PCDFs detected in Columbia River fish is 2,3,7,8-tetrachlorodibenzofuran $(2,3,7,8$-TCDF) because of its pervasiveness in fish from the vicinity of bleached-kraft pulp mills (Mah and others, 1989; Johnson and others, 1991). Since these compounds are present in the environment at low concentrations, they are usually reported in picograms per gram (pg/g) or parts per trillion in fish tissue. The U.S. Environmental Protection Agency (1993) considers dioxins and furans to be carcinogens. However, the full effects of dioxins and furans on human and environmental health are not fully understood, and therefore making conclusive statements about their effects at specific concentrations is not yet possible.

\section{Toxicity Equivalence Concentrations}

PCDDs and PCDFs with chlorine atoms located at the 2,3,7, and 8 positions (fig. 3) are considered the most toxic. There are 7 PCDDs and 10 PCDFs with this substitution pattern. To assess the toxicity of PCDD/ PCDF mixtures in fish, a set of toxicity equivalence factors (TEFs) are used to convert toxicity of each congener to that of 2,3,7,8-TCDD, called toxicity equivalent concentrations (TECs). Similar TEFs and TECs have been calculated for the toxic "dioxin-like" PCBs. An example of TEC calculations and summation of total toxicity for some dioxin congeners is given in table 1. The TEC values presented in this report are used for between site comparisons only and not for human health risk evaluation.

Table 1. An example table of toxicity equivalence concentration (TEC) calculations for some dioxin congeners [pg/g, picograms per gram]

\begin{tabular}{llll}
\hline & $\begin{array}{l}\text { Measured } \\
\text { concen- } \\
\text { tration } \\
\text { Dioxin congeners }\end{array}$ & $\begin{array}{l}\text { Toxicity } \\
\text { equivalence } \\
\text { factor } \\
\text { (TEF) }\end{array}$ & $\begin{array}{l}\text { Toxicity } \\
\text { equivalence } \\
\text { concentration } \\
\text { (TEC) }(\mathrm{pg} / \mathrm{g})\end{array}$ \\
\hline $2,3,7,8-\mathrm{TCDD}$ & 0.05 & 1 & 0.05 \\
$1,2,3,7,8-\mathrm{PeCDD}$ & 0.08 & 0.5 & 0.04 \\
$1,2,3,4,7,8-\mathrm{HxCDD}$ & 0.03 & 0.1 & 0.003 \\
$1,2,3,4,6,7,8-\mathrm{HpCDD}$ & 0.08 & 0.01 & 0.0008 \\
OCDD & 1.05 & 0.001 & 0.001 \\
\hline Total & & & \\
\hline
\end{tabular}

\section{Mercury}

Mercury can enter the atmosphere from natural sources (oceans and volcanoes) and human sources (burning waste and coal). Mercury can enter the aquatic environment through the atmosphere or precipitation, from the weathering of rock, or from wastes discharged from mines, smelters, and wastewater treatment plants. Some pesticides also contain mercury that can be washed into streams from urban and agricultural applications. Inorganic mercury that occurs naturally and in small quantities is not of human and environmental health concern. However, when mercury is present in an aquatic or sediment environment under 
anaerobic (without oxygen) conditions, sediment bacteria can change inorganic mercury into the more toxic organic forms of mercury. Organic forms of mercury are readily taken up in the tissue of aquatic organisms. These forms of mercury have toxic effects on aquatic organisms as well as fish-eating wildlife and can bioaccumulate up the food chain (Eisler, 1987). Mercury can therefore accumulate in the muscle tissue (fillet) of fish to levels that may pose a threat to human health (Erwin and Munn, 1997).

Previous studies of mercury in sediment (Bortleson and others, 1994) and fish tissue (Serdar, 1993) concluded that mercury in Lake Roosevelt was higher than background concentrations. Serdar (1993) reported that mercury concentrations were higher in walleye than in other species in the lake and that concentrations were elevated to levels that could pose a threat to human health. In 1997, the DOH released a health advisory based upon mercury data collected by the USGS (Erwin and Munn, 1997).

\section{METHODS}

This study was designed to permit a comparison of present concentrations of contaminants to those reported in the 1994 USEPA study (EVS Consultants, 1998) and 1994 USGS study (Munn and others, 1995), therefore decisions on fish species, sample locations, and chemical analysis were based on previous data. Fish were collected from two major reaches of Lake Roosevelt and the upper Columbia River (fig. 1). The upper reach extends from Kettle Falls to Northport, which includes both free-flowing river and the upper reservoir. The lower reach is exclusively reservoir and extends from the Spokane River down to Grand Coulee Dam. Fish collected included walleye (Stizostedion vitreum), wild and net-pen rainbow trout (Oncorhynchus mykiss), and mountain whitefish (Prosopium williamsoni). Rainbow trout collected from the lower reach in 1994 (EVS Consultants, 1998) were not separated into wild and net-pen; therefore, 1994 lower rainbow trout are referred to as mixed. Number of fish per location and analysis are presented in table 2. All fish were collected during the summer and fall of 1998 by

Table 2. Summary of study by contaminant group, data source, species, and location

[Samples were collected from the upper reach (Northport to Kettle Falls) and lower reach (Spokane River to Grand Coulee Dam) of Lake Roosevelt. The 1994 mercury study was done by the U.S. Geological Survey and the 1994 dioxin and furan, and PCB study was done by EVS Consultants (1998). The U.S. Geological Survey did all contaminant groups in 1998. Samples with the same letter were compared statistically; --, data not collected]

\begin{tabular}{|c|c|c|c|c|c|c|c|}
\hline \multirow{2}{*}{$\begin{array}{l}\text { Contaminant } \\
\text { group }\end{array}$} & \multirow{2}{*}{$\begin{array}{l}\text { Data } \\
\text { source }\end{array}$} & \multicolumn{2}{|c|}{$\begin{array}{c}\text { Walleye } \\
\text { (13-16 inches) }\end{array}$} & \multicolumn{2}{|c|}{$\begin{array}{l}\text { Wild rainbow trout } \\
\text { (14-23 inches) }\end{array}$} & \multirow{2}{*}{$\begin{array}{c}\text { Net-pen } \\
\text { rainbow trout } \\
\text { (13-23 inches) } \\
\text { Lower }\end{array}$} & \multirow{2}{*}{$\begin{array}{c}\text { Mountain } \\
\text { Whitefish } \\
\text { (17-21 inches) } \\
\text { Upper }\end{array}$} \\
\hline & & Upper & Lower & Upper & Lower & & \\
\hline \multirow[t]{2}{*}{ PCB 1254} & EPA 1994 & -- & -- & $23 a$ & -- & $7 b^{*}$ & -- \\
\hline & USGS 1998 & -- & -- & $8 \mathrm{a}$ & $8 b$ & $8 b$ & -- \\
\hline \multirow{2}{*}{$\begin{array}{l}\text { Dioxins/ } \\
\text { furans }\end{array}$} & EPA 1994 & -- & -- & $23 \mathrm{c}$ & -- & $7 d^{*}$ & $8 \mathrm{e}$ \\
\hline & USGS 1998 & -- & -- & $8 c$ & $8 d$ & $8 d$ & $5 e$ \\
\hline $\begin{array}{l}\text { Toxic “Dioxin } \\
\text { like" PCB } \\
\text { congeners }\end{array}$ & USGS 1998 & -- & -- & 2 & 2 & 4 & -- \\
\hline \multirow[t]{2}{*}{ Mercury } & USGS 1994 & $8 \mathrm{f}$ & $8 g$ & -- & -- & -- & -- \\
\hline & USGS 1998 & $8 \mathrm{f}$ & $8 \mathrm{~g}$ & -- & -- & -- & -- \\
\hline
\end{tabular}

* The 1994 USEPA (EVS Consultants, 1998) study did not separate net-pen and wild rainbow trout, therefore, concentrations presented in this report may reflect a combination of both groups. 
the Spokane Tribe using a combination of an electroshock boat and gill nets. Fish were processed in a similar fashion with minor differences outlined below. Upon collection, fish were sacrificed, placed in a labeled plastic bag if used for mercury analysis and in foil if used for organic analyses. Samples were frozen on dry ice and shipped to the laboratory for processing.

The first processing step was to collect basic physical information on each fish: total length, from the most anterior part of the fish to the tip of the longest caudal fin ray, in centimeters; and total weight, in grams. Processing equipment was made of glass or stainless steel. Strict guidelines were followed in the cleaning of all equipment that came into contact with samples, and equipment was cleaned between each fish sampling. Cleaning procedures included washing equipment with phosphate-free laboratory detergent solution and rinsing in Type I reagent-grade water (Munn and others, 1995).

Individual fillet samples were removed in accordance with procedures in USEPA (1995), which include the belly flap. For the mercury portion of this study, skin was removed on the individual walleye fillets; whereas, for the other contaminants and species, the skin was left on. Once a fillet was removed it was frozen and shipped on dry ice to the appropriate laboratory for analysis.

Rainbow trout and mountain whitefish were analyzed for dioxins and furans using USEPA Method 1613B (U.S. Environmental Protection Agency, 1994), which analyzed for 17 dioxin and furan congeners. Also, rainbow trout samples were analyzed for PCB Aroclors using USEPA method 8082 (U.S. Environmental Protection Agency, 1998) along with a small subset of samples analyzed for 13 individual toxic "dioxin-like" PCB congeners using USEPA Method 1668 (U.S. Environmental Protection Agency, 1995b). All fish tissue contaminant values are reported as wet weight. Standard quality assurance and quality control procedures were used for all laboratory analysis and resulted in all data meeting quality criteria. Samples were analyzed for PCBs, dioxins, and furans, by Axys Analytical in Victoria, B.C.

Walleye samples were shipped to the USGS trace-element laboratory in Atlanta, Georgia, where they were analyzed for total mercury using a cold vapor atomic absorption method (Elrick and Horowitz, 1986). Concentrations of mercury are presented as $\mathrm{mg} / \mathrm{kg}$, wet weight.
Statistical analysis was performed using an indicator contaminant for each contaminant group. For PCB, Aroclor 1254 was used to compare between 1994 and 1998; whereas for dioxin and furans the furan congener 2,3,7,8-TCDF was used. These were selected because they were detected in all samples and therefore prevented statistical problems associated with nondetections. Because sample sizes were small and therefore distributions uncertain, the non-parametric Kruskal-Wallis or the Mann-Whitney U tests were used to determine if concentrations had changed from 1994 to 1998 . Tests were considered to be significant when $\mathrm{P}<0.05$; if a statistical test was found to be non-significant, then a statistical power (1- $\beta$ ) was calculated. Tukey's LSD test was used as the multicomparison test on ranked data (Helsel and Hirsch, 1992).

\section{RESULTS}

Concentrations of contaminants in fish that were identified as a potential threat to human health have either not changed since the 1994 studies, or have decreased. Presented and discussed below are results of analyses for PCBs, dioxins and furans, toxicity equivalent concentrations, and mercury. Data on the concentrations of contaminants summarized in this report can be obtained from the Washington District web site at

http://wa.water.usgs.gov/LakeRoosevelt/

\section{PCBs}

\section{Median concentrations of PCB Aroclor 1254 in 1994 rainbow trout were similar to 1998 rainbow trout.}

Historically, all PCB studies on Lake Roosevelt and the upper Columbia River have focused on PCB Aroclors 1242, 1254, and 1260. While this study examined all three PCB Aroclors, we relied on the 1254 concentrations for statistical comparisons. The median concentrations of Aroclor 1254 in rainbow trout collected in 1998 were $24 \mu \mathrm{g} / \mathrm{kg}(16-43 \mu \mathrm{g} / \mathrm{kg})$ for upper reach wild rainbow trout, $15.5 \mu \mathrm{g} / \mathrm{kg}$ $(8.8-49 \mu \mathrm{g} / \mathrm{kg})$ for lower reach wild rainbow trout, and $5.7 \mu \mathrm{g} / \mathrm{kg}(3.3-35 \mu \mathrm{g} / \mathrm{kg})$ for lower reach net-pen rainbow trout. For the upper reach, no significant difference was found in the concentration of Aroclor 1254 
between $1994($ median=21.6 $\mu \mathrm{g} / \mathrm{kg})$ and 1998

(median $=24 \mu \mathrm{g} / \mathrm{kg}$ ) rainbow trout (Mann-Whitney $\mathrm{U}$

Test $=91, \mathrm{P}=0.96)$. However, additional analysis determined that there was insufficient power $(1-\beta=0.05)$ to detect a difference among the 2 years due to the high variability. The high variability could be due to several reasons: uneven sample size (23 in 1994 and 8 in 1998), naturally high variability due to the distribution of PCBs in the system, and differences in the processing and laboratory analysis between the 2 years.

In the lower reach, a significant difference was found among the three trout groups (Kruskal-Wallis test, $\mathrm{P}<0.05$ ). Multiple comparison tests (Tukey's LSD on ranked data) determined that there was no significant difference between the 1994 mixed rainbow trout (median=15.6 ppb) and the 1998 wild rainbow trout (median=15.5 ppb), but that the concentration of 1254 in 1998 net-pen rainbow trout (median $=5.7 \mathrm{ppb}$ ) was significantly lower (fig. 4).

\section{Dioxins and Furans}

Dioxins and furans are still present in Lake Roosevelt sport fish, and concentrations of $2,3,7,8$ TCDF did decrease from 1994 to 1998 in rainbow trout. However, there was no apparent change in the 2,3,7,8-TCDF concentrations in mountain whitefish. Median concentrations of 2,3,7,8-TCDF were higher in mountain whitefish than in rainbow trout.

This 1998 USGS study found dioxins (PCDDs) and furans (PCDFs) present in all fish samples collected including wild and net-pen rainbow trout and whitefish. Total concentrations of PCDDs+PCDFs ranged from $1.1 \mathrm{pg} / \mathrm{g}$ in net-pen rainbow trout to $6.0 \mathrm{pg} / \mathrm{g}$ in whitefish from the upper reach, with PCDF making up over 70 percent of the total in most samples (fig. 5). Median concentrations of 2,3,7,8-TCDF were about the same in wild rainbow trout collected from the upper $(0.74 \mathrm{pg} / \mathrm{g})$ and lower $(0.68 \mathrm{pg} / \mathrm{g})$ reaches, but

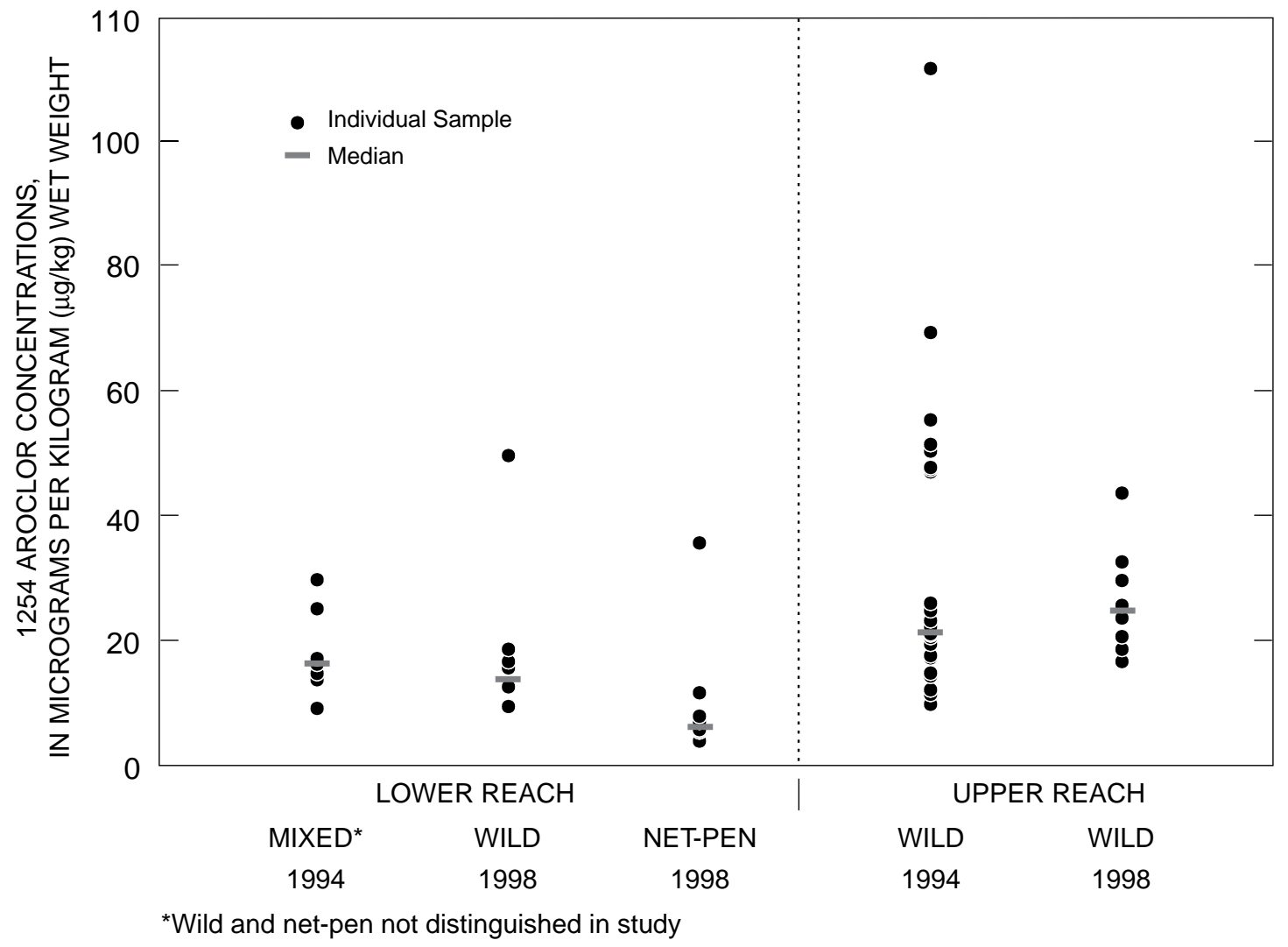

Figure 4. Concentrations of 1254 Aroclor from 1994 (EVS Consultants, 1998) and 1998 studies. Individual rainbow trout fillet samples from upper and lower reaches of Lake Roosevelt, Washington. 


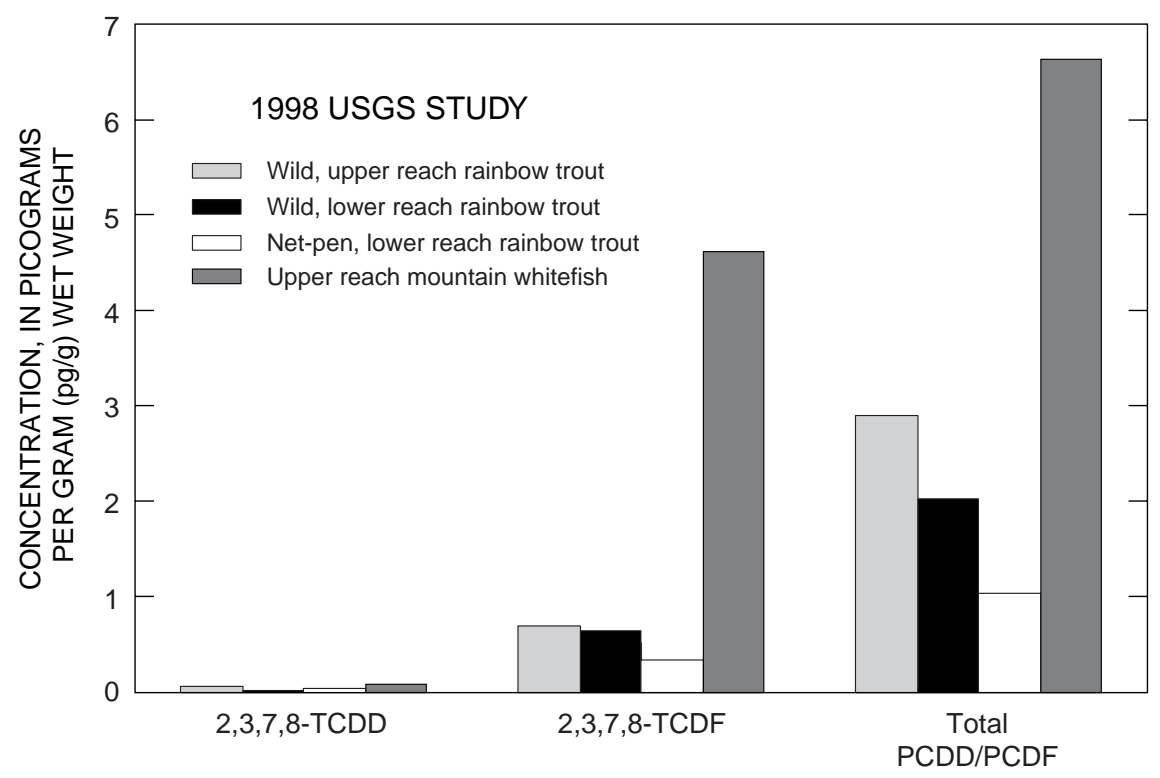

Figure 5. Median concentrations of dioxins and furans in rainbow trout and mountain whitefish from the upper and lower reaches of Lake Roosevelt, Washington, 1998.

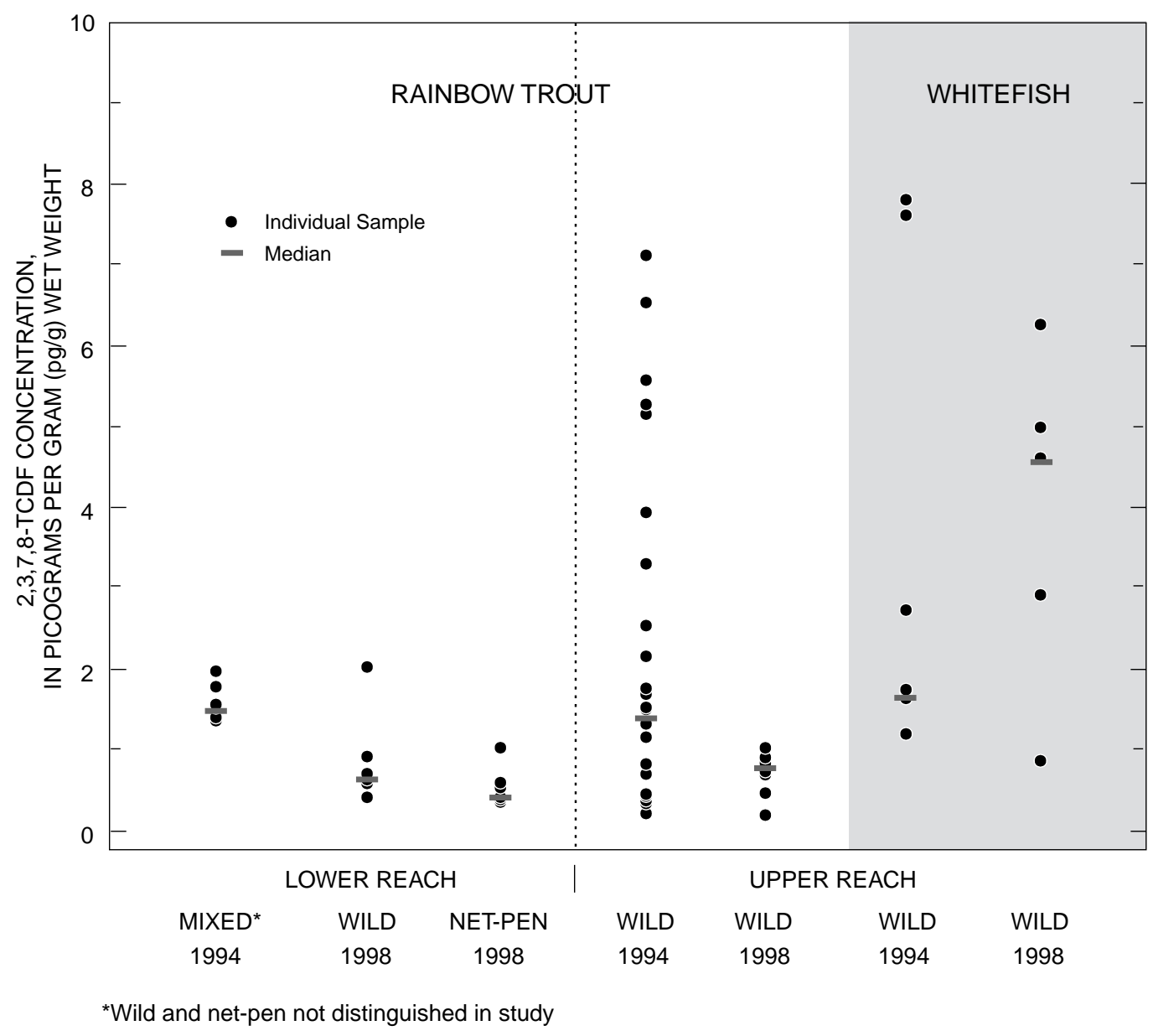

Figure 6. Concentrations of 2,3,7,8-TCDF in rainbow trout and mountain whitefish fillet samples from the upper and lower reaches of Lake Roosevelt, Washington. 
concentrations were slightly lower in net-pen rainbow trout $(0.42 \mathrm{pg} / \mathrm{g})$ collected in the lower reach. In contrast, 2,3,7,8-TCDF in whitefish collected from the upper reach had a median concentration of $4.61 \mathrm{pg} / \mathrm{g}$.

Although dioxins and furans are present in all fish tissue sampled, the concentrations of 2,3,7,8TCDF in rainbow trout have decreased, but there is no apparent change in concentrations of 2,3,7,8-TCDF in mountain whitefish (fig. 6). Three statistical comparisons were made for 2,3,7,8-TCDF concentrations. First, 2,3,7,8-TCDF concentrations in wild rainbow trout from the upper reach have significantly decreased (Mann-Whitney U-test, P<0.05) from 1994 to 1998. The median concentration in 1994 was $1.5 \mathrm{pg} / \mathrm{g}$, decreasing to $0.74 \mathrm{pg} / \mathrm{g}$ in 1998 . Second, concentrations of 2,3,7,8-TCDF were significantly different among the three rainbow trout groups (1994 mixed rainbow trout, 1998 net-pen rainbow trout, and 1998 wild rainbow trout) in the lower reach (Kruskal-Wallis test, $\mathrm{P}<0.05)$. Tukey's multiple comparison test on ranked data determined that of the three groups, 2,3,7,8-TCDF concentrations in 1994 mixed rainbow trout were significantly higher (median $=1.5 \mathrm{pg} / \mathrm{g}$, $\mathrm{P}<0.05)$ than concentrations in either 1998 wild rainbow trout (median $=0.68$ ) or net-pen rainbow trout (median=0.42), with the 1998 groups not different from each other $(\mathrm{P}>0.05)$. Third, in contrast to the rainbow trout, there was no significant difference (Mann-Whitney U test, $\mathrm{P}>0.05$ ) in the concentration of 2,3,7,8-TCDF in mountain whitefish collected from the upper reach between 1994 and 1998. However, it is important to note that as in the PCB statistics, there was high variability in 2,3,7,8-TCDF concentrations for both years along with a small sample size in both 1994 $(n=8)$ and $1998(n=5)$. This resulted in a low statistical power $(1-\beta=0.10)$ for distinguishing differences between years.

The decrease in 2,3,7,8-TCDF in rainbow trout between 1994 and 1998 likely reflects the changes in pulp mill processing upstream and substantiates earlier studies that dioxins and furans are decreasing over time (EVS Consultants, 1998). However, although there is a decrease in dioxins and furans in rainbow trout, concentrations of 2,3,7,8-TCDF in mountain whitefish remained elevated for unknown reasons. The issue of higher concentrations of 2,3,7,8-TCDF may reflect the trophic position of whitefish compared with rainbow trout. Rainbow trout in the Columbia River/Lake Roosevelt system feed heavily on plankton and benthic invertebrates at particular times or locations.
In contrast, mountain whitefish in the upper system are primarily benthic feeders, so they would tend to consume food that is in more direct contact with contaminated sediments.

\section{Toxicity Equivalence Concentrations}

\section{Rainbow trout from the upper reach have higher toxicity equivalent concentrations (TECs) than rainbow trout from the lower reach, with trout from the upper reach having a higher per- centage of the toxicity from toxic "dioxin-like" PCBs than dioxin and furan compounds.}

For the PCDD and PCDF congeners and the toxic "dioxin-like" PCBs in 1998 rainbow trout, TECs were calculated to give relative toxicity values for the upper and lower reaches. The results of this analysis provide a preliminary screening of the combined toxicity of these organochlorine compounds in Lake Roosevelt sport fish. Figure 7 summarizes the TECs for rainbow trout. The total TEC for all dioxin-like compounds was highest in the upper reach rainbow trout, with an overall average (PCDD, PCDF, and PCB) TEC of $0.9 \mathrm{pg} / \mathrm{g}$. The average TECs for the lower reach net-pen rainbow trout $(0.3 \mathrm{pg} / \mathrm{g})$ were similar to the lower reach wild rainbow trout $(0.4 \mathrm{pg} / \mathrm{g})$. For both the upper and lower reaches the "dioxin-like" PCBs composed the largest portion of the total toxicity, especially in the upper reach, where the "dioxin-like" PCBs accounted for more than 70 percent of the total toxicity. Further studies are needed to determine the source as well as the human and wildlife health effects of the toxic "dioxin-like" PCBs in Lake Roosevelt.

\section{Mercury}

\section{The concentrations of total mercury in walleye have decreased by about 50 percent from 1994 to 1998.}

This study found that total mercury in walleye fillets decreased (Mann-Whitney U test, $\mathrm{P}<0.05$ ) between 1994 and 1998 (fig. 8). Median concentrations of mercury in 13- to 16-inch walleye collected from the upper reach decreased significantly from $0.18 \mathrm{mg} / \mathrm{kg}$ to $0.11 \mathrm{mg} / \mathrm{kg}$ and decreased from 0.26 to $0.15 \mathrm{mg} / \mathrm{kg}$ in the lower reach.

Two possible explanations can be given for the decrease in mercury concentrations in walleye tissue. 


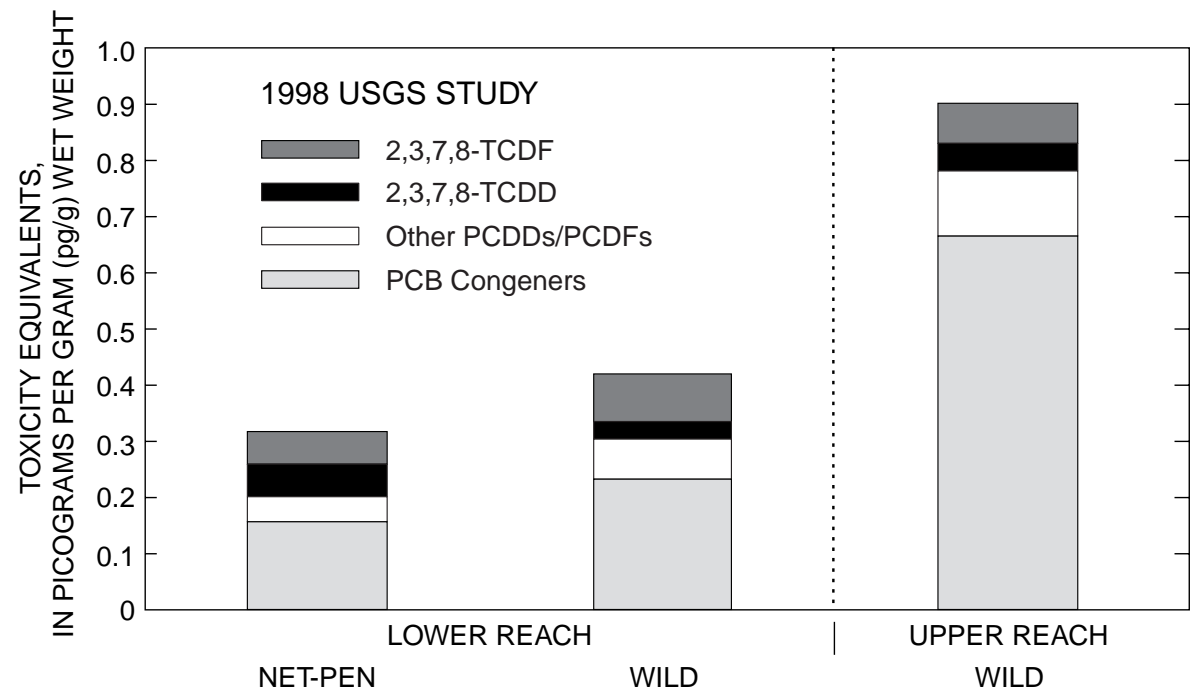

Figure 7. Toxicity equivalent concentrations (TECs) for 1998, dioxins and furans, and $\mathrm{PCB}$ congener values in rainbow trout from the upper and lower reaches of Lake Roosevelt, Washington.

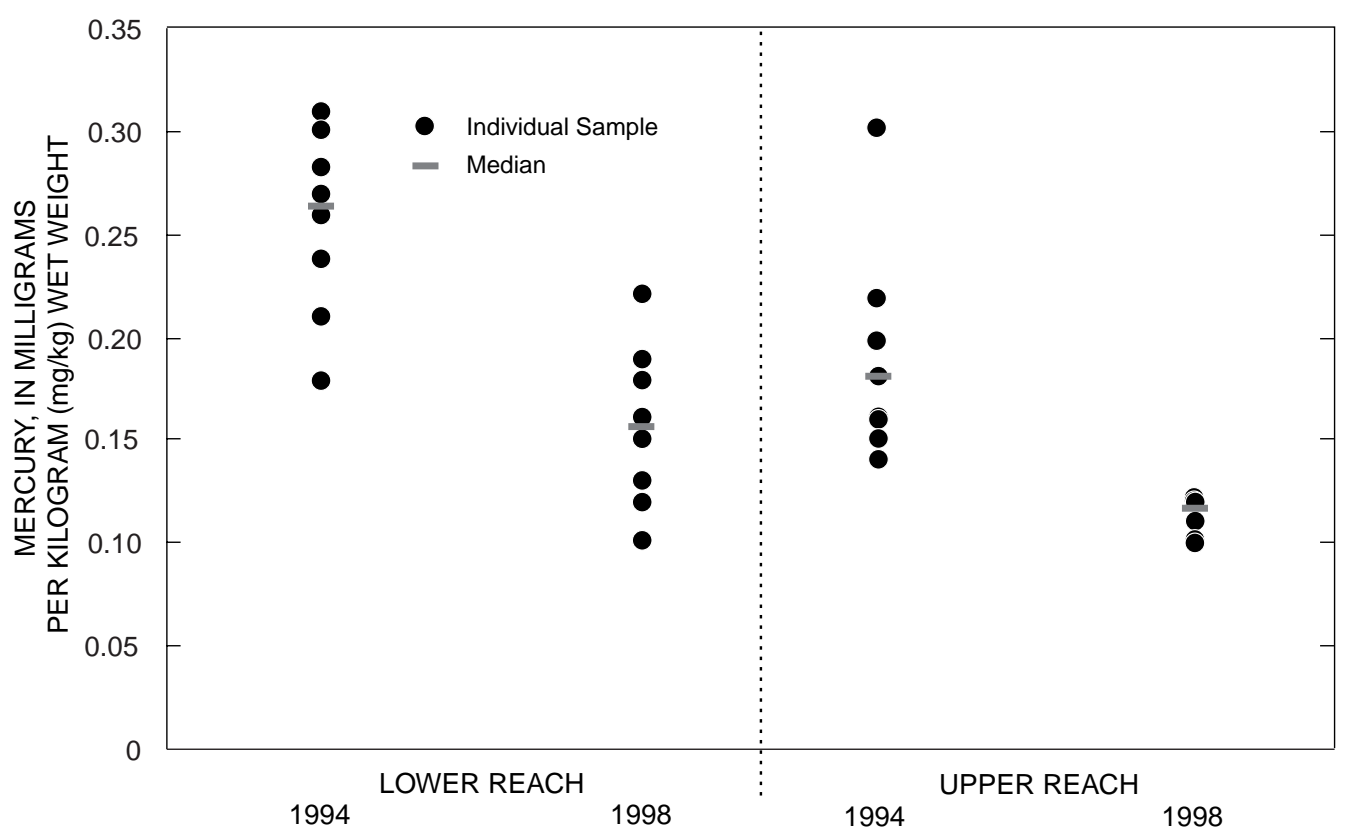

Figure 8. Concentrations of total mercury in walleye fillet tissue from the upper and lower reaches of Lake Roosevelt, Washington, 1994 and 1998. 
One explanation may be related to the decrease in discharge from industrial sources. Although mercury can originate from both natural and human processes, a major source of mercury to the upper Columbia River system was believed to be the Cominco lead-zinc smelter in Trail, B.C., 10 miles north of the international border. The smelter has recently reduced its overall discharge of effluent, which may be a major reason for the reduction of mercury in the upper reach (Serdar and others, 1994). There are other potential sources of mercury to the lower reach of Lake Roosevelt from the Spokane River that drains the Coeur d'Alene Basin. Although the Coeur d'Alene Basin and Spokane River have been studied extensively for metals (Johnson and others, 1994), mercury input to the Spokane arm of Lake Roosevelt has not been well documented.

Another explanation of reduced mercury concentrations in walleye may be the substantial change in flow management in Lake Roosevelt since 1994. In 1994, the retention time of water in the reservoir was approximately 40 days. Over the last few years the retention time has decreased somewhat due to flow requirements downstream. Because the reduction in retention time probably does not allow the lake sediments to become anoxic, which is required for the production of organic forms of mercury, the potential for mercury bioaccumulation is reduced. Although mercury sources have been documented, the spatial and temporal trends in mercury concentrations in Lake Roosevelt fish tissue are not fully understood. While industrial input has been reduced and flow management has changed in Lake Roosevelt, it is important to note that mercury does not leave a system rapidly and may persist in the bed sediments as well as fish tissue.

\section{CONCLUSIONS}

Contaminants examined in this study are either decreasing in fish tissue, or remaining the same, depending on the contaminant and fish species. Concentrations of PCBs in rainbow trout remain elevated and do not appear to be decreasing. Although dioxins and furans are still present in sport fish, concentrations of 2,3,7,8-TCDF have decreased in rainbow trout, but not in whitefish. It is presently unknown why concentrations of 2,3,7,8-TCDF in whitefish are higher than rainbow trout or why concentrations have not changed. Total mercury decreased in walleye from 1994 to 1998. The decrease in some of the contaminants found in sport fish is thought to be a function of reductions in industrial loadings to the Columbia River, but could also be partially due to changes in reservoir management practices. It is unknown whether reservoir management practices in the future will affect the concentrations or distribution of contaminants in Lake Roosevelt.

\section{REFERENCES CITED}

Bortleson, G.C., Cox, S.E., Munn, M.D., Schumaker, R.J., and Block, E.K., 1994, Sediment-quality assessment of Franklin D. Roosevelt Lake and the upstream reach of the Columbia River, Washington, 1992: U.S. Geological Survey Open-File Report 94-315, 130 p., 1 pl.

Eisler, R., 1987, Mercury hazards to fish, wildlife, and invertebrates--a synoptic review: U.S. Fish and Wildlife Service, Biological Report 85 (1.10), 90 p.

Elrick, K.A., and Horowitz, A.J., 1986, Analysis of rocks and sediments for mercury, by wet digestion and flameless cold vapor atomic absorption: U.S. Geological Survey Open-File Report 86-596, 12 p.

Erwin, M.L., and Munn, M.D., 1997, Are walleye from Lake Roosevelt contaminated with mercury? U.S. Geological Survey Fact Sheet 102-97, 4 p.

EVS Consultants, 1998, Assessment of dioxins, furans, and PCBs in fish tissue from Lake Roosevelt, Washington, 1994: Seattle, Washington, U.S. Environmental Protection Agency, 53 p.

Helsel, D.R., and Hirsch, R.M., 1992, Statistical methods in water resources: New York, Elsevier Pub., Studies in Environmental Science 49, 522 p.

Johnson, A., Serdar, D., and Davis, D., 1994, Results of 1993 screening survey on PCBs and metals in the Spokane River: Olympia, Wash., Washington State Department of Ecology, 21 p.

Johnson, A., Serdar, D., and Magoon, S., 1991, Polychlorinated dioxins and furans in Lake Roosevelt (Columbia River) sportfish, 1990: Olympia, Wash., Washington State Department of Ecology, Publication no. 91-4, $47 \mathrm{p}$.

Mah, F.T.S., MacDonald, D.D., Sheehas, S.W., Tuominen, T.M., and Valiela, D., 1989, Dioxins and furans in sediment and fish from the vicinity of ten inland pulp mills in British Columbia: North Vancouver, B.C., Water Quality Branch, Inland Waters Directorate, Environment Canada, 77 p.

Munn, M.D., Cox, S.E., and Dean, C.J., 1995, Concentrations of mercury and other trace elements in walleye, smallmouth bass, and rainbow trout in Franklin D. Roosevelt Lake and the upper Columbia River, Washington, 1994: U.S. Geological Survey Open-File Report 95-195, 35 p. 
Serdar, D., 1993, Retrospective analysis of toxic contaminants in Lake Roosevelt, Draft No. 2: Olympia, Wash., Evergreen State College, 89 p.

Serdar, D., Yake, B., and Cubbage, James, 1994, Contaminant trends in Lake Roosevelt: Olympia, Wash., Washington State Department of Ecology, Publication no. 94-185, 32 p.

Smith, J.A., Witkowski, P.J., and Fusillo, T.V., 1988, Manmade organic compounds in surface waters of the United States--a review of current understanding: U.S. Geological Survey Circular 1007, 92 p.

U.S. Environmental Protection Agency, 1993, Interim report on data and methods for assessment of 2,3,7,8-tetrachlorodibenzo-p-dioxin risks to aquatic life and associated wildlife: Washington, D.C., U.S. Environmental Protection Agency, EPA/600/R-93/055, [variously paged].
1994, Method 1613--revision B, tetra-through octa-chlorinated dioxins and furans by isotope dilution HRGC/HRMS: U.S. Environmental Protection Agency, Office of Water, Washington, D.C., 48 p. 1995a, Guidelines for assessing chemical contaminant data for use in fish advisories, v. 1, fish sampling and analysis: Washington, D.C., Environmental Protection Agency report 823-R-93-002, 289 p. 1995b, Toxic polychlorinated biphenyls by isotope dilution high resolution gas chromatography/high resolution mass spectrometry: U.S. Environmental Protection Agency, Office of Water, Washington, D.C., 66 p.

1998, EPA Method 8082A--polychlorinated biphenyls (PCBs) by gas chromatography, revision 1--EPA test methods for evaluating solid wastes, physical/ chemical methods: SW-846, 48 p. 


\section{UPDATE FROM THE WASHINGTON STATE DEPARTMENT OF HEALTH REGARDING CONSUMPTION OF LAKE ROOSEVELT CAUGHT FISH}

In 1994, the U.S. Geological Survey (USGS) conducted a study on Lake Roosevelt to assess mercury concentrations in walleye. The results of this study were summarized in the USGS fact sheet "Are walleye from Lake Roosevelt contaminated with mercury?" Recent studies have provided improved information regarding present concentrations of contaminants in Lake Roosevelt fish, the toxicity of mercury, and the consumption of fish by Lake Roosevelt anglers. DOH used this information in a human health assessment and is providing the following updated recommendations regarding the consumption of fish from Lake Roosevelt.

\section{Mercury}

A recently completed study by $\mathrm{DOH}$ concludes that mercury in fish may be slightly more toxic than previously thought. DOH has proposed a tolerable daily intake (TDI) developed to protect children from impaired neurological development and other longterm effects resulting from prenatal exposure to methylmercury. This TDI, defined as an amount that can be consumed daily that is not expected to have any adverse health impacts, ranges from $0.035-0.08$ micrograms of mercury per kilogram bodyweight per day $\mu \mathrm{g} / \mathrm{kg} /$ day). This TDI incorporates the findings of recently published studies and is more protective than the Environmental Protection Agency's value of $0.1 \mu \mathrm{g} / \mathrm{kg} / \mathrm{day}$.

In 1994 and 1995, DOH in cooperation with the Spokane Tribe of Indians surveyed anglers on Lake Roosevelt, primarily at recreational boat launch facilities, to determine how much and how often locally caught fish are consumed. Based on these results and results from the recent USGS study, which found decreasing mercury concentrations in fish, we do not expect individuals to experience any adverse health effects from consuming fish with the reported mercury concentrations. This includes the populations of greatest concern, which consist of women of child bearing age and their offspring.

\section{PCBs and Dioxins}

While scientists and health professionals worldwide acknowledge that exposure to PCBs and dioxins should be minimized, there is currently no agreement on what level of exposure is deemed to not result in adverse health effects. Presently, DOH is unable to provide specific recommendations regarding the consumption of fish from Lake Roosevelt, which contain trace amounts of these compounds.

\section{DOH recommendations for reducing your exposure to contaminants in fish:}

Fish are an important part of a healthy diet. They are an excellent source of protein, are low in saturated fats, and contain beneficial oils such as omega-3 polyunsaturated fatty acids, which are thought to help reduce cholesterol levels, high blood pressure, and the risk of coronary heart disease. (The American Heart Association recommends people eat two to three meals of fish per week.)

Based on the most recent data, DOH does not expect anglers to experience any adverse health effects from eating fish taken from Lake Roosevelt due to mercury contamination. To reduce your exposure to other contaminants found in fish, the following general recommendations are provided.

1. Consume younger and therefore smaller fish (within legal limits) since they generally contain lower concentrations of contaminants than older, larger fish.

2. Avoid eating bottom fish such as catfish, carp, or sucker, which feed on the bottom and are likely to contain higher levels of chemical contamination.

3. When you clean the fish, remove the skin, fat, and internal organs before you cook the fish, as these tissues commonly contain higher concentrations of environmental contaminants.

4. Cook the fish so that the fat is allowed to drip off. Recommended cooking methods include: grilling, baking, or broiling.

5. Remember that with any fresh meat, always follow proper food handling and storage techniques. To prevent the growth of bacteria, keep freshly caught fish on ice and out of direct sunlight.

For more information, contact DOH at 1-877-485-7316 or your local health department. Visit the DOH web page at: http://www.doh.wa.gov/ 